\title{
KEBIJAKAN UNTUK KEBERLANJUTAN EKOLOGI, SOSIAL, EKONOMI DAN BUDIDAYA KERAMBA JARING APUNG DI WADUK CIRATA
}

\author{
Aceng Hidayat ${ }^{1 *}$, Zukhruf Annisa ${ }^{2}$, Prima Gandhi ${ }^{1}$ \\ ${ }^{1}$ Departemen Ekonomi Sumberdaya dan Lingkungan Institut Pertanian Bogor \\ ${ }^{2}$ Mayor Departemen Ekonomi Sumberdaya dan Lingkungan Institut Pertanian Bogor \\ *Email: a.hidayat.esl@gmail.com
}

\begin{abstract}
RINGKASAN
Cirata merupakan nama waduk terbesar di Jawa Barat yang memiliki fungsi utama sebagai pembangkit listrik tenaga air (PLTA) untuk pasokan listrik wilayah pulau Jawa dan Bali. Selain menyediakan pasokan listrik, waduk ini juga dimanfaatkan untuk kegiatan perikanan tangkap, perikanan budidaya keramba jaring apung $(\mathrm{KJA})$, transportasi dan pariwisata. Aktivitas di perairan waduk yang melebihi daya dukung lingkungan menimbulkan permasalahan tersendiri yang dapat mengancam status keberlanjutan waduk sebagai PLTA maupun sebagai perairan umum daratan, sehingga diperlukan pengelolaan waduk yang berkelanjutan. Penelitian ini bertujuan untuk menganalisis status keberlanjutan waduk dan keberlanjutan budidaya KJA dalam multidimensi keberlanjutan (ekologi, ekonomi dan sosial). Analisis dilakukan secara multidimentional scaling dengan alat analisis Rapid Appraisal for Fisheries Status (Rapfish), dilanjutkan dengan analisis sensitivitas dan ketidakpastian menggunakan analisis Monte Carlo dan Leverage. Berdasarkan hasil penelitian status keberlanjutan waduk dan budidaya KJA termasuk dalam status kurang berkelanjutan. Status keberlanjutan Waduk Cirata lebih baik dari status keberlanjutan budidaya KJA yang terdapat di perairan waduk, hal ini dapat dilihat dari nilai indeks keberlanjutan budidaya KJA yang cenderung lebih besar. Kondisi keberlanjutan waduk dan budidaya KJA sangat mempengaruhi satu sama lain, yang artinya kondisi buruk salah satu elemen keberlanjutan akan menghambat terwujudnya keberlanjutan yang lainnya. Rekomendasi kebijakan yang disarankan adalah implementasi kebijakan pembatasan jumlah KJA, perbaikan struktur harga jual, kebijakan penegakan hukum dan ketegasan aparat terhadap pelanggaran.
\end{abstract}

Kata kunci: Waduk Cirata, keberlanjutan, keramba jaring apung (KJA), rapfish

\section{PERNYATAAN KUNCI}

- Undang-Undang Republik Indonesia Nomor 31 Tahun 2004 sebagaimana diubah dengan UU No. 45 Tahun 2009 pasal 7 tentang Perikanan bahwa perairan umum daratan seperti sungai, danau, waduk, rawa, dan genangan air lainnya yang berada dalam kedaulatan Republik Indonesia dapat diusahakan sebagai lahan pembudidayaan ikan dengan tetap memperhatikan daya dukung dan kelestariannya untuk dimanfaatkan sebesarbesarnya bagi kesejahteraan dan kemakmuran rakyat Indonesia. 
- Pembatasan terhadap jumlah KJA sebanyak 12.000 unit telah dilakukan oleh pemerintah Provinsi Jawa Barat pada tahun 2002 melalui Surat Keputusan Gubernur Nomor 41/2002 tentang pembatasan jumlah KJA, namun pada pelaksanaannya jumlah KJA saat ini mencapai 70.000 unit melebihi batas maksimum yang telah ditentukan. Kegagalan pengelola waduk ini diduga akan mengacam keberlanjutan waduk dan KJA di Waduk Cirata.

- Faktor-faktor yang memengaruhi keberlanjutan adalah ekologi, ekonomi dan sosial. Status keberlanjutan waduk dan sumberdaya perikanan dapat dianalisis menggunakan analisis multidimensi dengan alat analisis Rapid Appraisal for fisheries status (Rapfish). Rapfish merupakan teknik multidiciplinary rapid appraisal terbaru untuk mengevaluasi status keberlanjutan berdasarkan beberapa atribut yang mudah diskoring. Rapfish didasarkan pada teknik ordinasi (menetapkan sesuatu pada urutan atribut yang terukur) dengan Multi-Dimensional Scaling (MDS). MDS merupakan teknik statistik dengan melakukan transformasi multidimensi kedalam dimensi yang lebih rendah.

\section{REKOMENDASI KEBIJAKAN}

- Pemerintah harus mengimplementasikan kebijakan pembatasan jumlah KJA sesuai daya tampung waduk, pengoptimalan budidaya KJA menggunakan sistem dua lapis jaring, penanaman lahan pinggiran waduk dan pengurangan aktivitas buruh waduk di atas perairan waduk.

- Pemerintah harus meningkatan kualitas ekologi waduk untuk menunjang keberlanjutan waduk dan budidaya KJA.

- Kebijakan-kebijakan yang dapat meningkatkan efisiensi, misalnya perbaikan struktur harga jual ikan melalui mekanisme lelang yang transparan, peningkatan kemampuan masyarakat dalam pengolahan ikan pasca panen untuk meningkatkan nilai tambah, pengolahan limbah enceng gondok sebagai bahan pakan ikan alternatif. Membatasi atau mengurangi kepemilikan modal usaha perikanan dari luar wilayah yang bersifat profit semata. Implementasi kebijakan biaya lingkungan pada budidaya KJA oleh BPWC.

- Pemerintah harus tegas menyelesaikan konflik melalui kebijakan penegakan hukum maupun ketegasan aparat terhadap pelanggaran yang dilakukan. Reimplementasi tugas Pokmaswas. Peningkatan pendidikan atau kemampuan petani ikan terkait kesadaran akan keberadaan waduk yang berkelanjutan.

\section{PENDAHULUAN}

Cirata adalah salah satu waduk terbesar di Jawa Barat yang dimanfaatkan sebagai pemasok kebutuhan listrik untuk wilayah Jawa dan Bali. Selain untuk pembangkit listrik tenaga air (PLTA), Waduk cirata dimanfaatkan sebagai lokasi pembudidayaan ikan menggunakan sistem keramba jaring apung (KJA), perikanan tangkap, tempat pariwisata, aktivitas pertanian, dan aktivitas domestik lainnya. Pemanfaatan perikanan tangkap, wisata, dan aktivitas domestik lainnya juga semakin berkembang, sehingga mengakibatkan terjadinya pencemaran, sedimentasi bahkan kerusakan sumberdaya alam Waduk Cirata. 
Dampak yang timbul akibat aktivitas pemanfaatan waduk ini menyebabkan terjadinya penurunan fungsi Waduk Cirata, meliputi penurunan produktivitas perikanan, serta menyebabkan korosi pada peralatan pembangkit listrik sehingga menyebabkan peningkatan biaya operasional kegiatan PLTA. Sedimentasi tinggi menyebabkan penurunan usia fungsi waduk dan meningkatnya frekuensi upwelling. Pencemaran, sedimentasi dan kerusakan yang terjadi ini sangat mengancam keberlanjutan fisik dan fungsi Waduk Cirata. Kondisi ini menandakan bahwa pengelolaan Waduk Cirata kurang efektif.

Pembatasan jumlah KJA sebanyak 12.000 unit telah dilakukan oleh pemerintah Provinsi Jawa Barat pada tahun 2002 melalui Surat Keputusan Gubernur Nomor 41/2002 tentang pengembangan dan pemanfaatan lahan pertanian dan kawasan waduk, namun faktanya jumlah KJA saat ini mencapai 70.000 unit melebihi batas maksimum yang telah ditentukan. Kegagalan pengelola waduk ini diduga akan mengancam status keberlanjutan waduk dan KJA di Waduk Cirata, sehingga perlu dilakukan kajian terhadap status keberlanjutan Waduk Cirata dan keberlanjutan usaha budidaya KJA di waduk melalui analisis keberlanjutan.

Analisis keberlanjutan dilakukan dengan tiga dimensi yaitu dimensi ekologi, ekonomi dan sosial. Kemudian dari ketiga dimensi tersebut dibagi menjadi indikator-indikator lebih rendah. Untuk menguji ketidakpastian dan anomali maka dilakukan Analisis RAPFISH, Analisis Monte Carlo dan Analisis Leverage. Hasil dari analisis tersebut berupa indeks keberlanjutan yang mendeskripsikan kondisi keberlanjutan waduk dan budidaya KJA yang dapat dijadikan acuan sebagai dasar kebijakan pengelolaan Waduk Cirata yang berkelanjutan.

\section{II.SITUASI TERKINI}

Waduk Cirata menghasilkan energi sebesar 1426 KWH/tahun dengan kapasitas 1008 MW yang memenuhi kebutuhan energi listrik di Jawa dan Bali. Energi tersebut dihasilkan dari 8 turbin yang bergerak oleh adanya tekanan air yang mengalir dari waduk dengan tinggi jatuh 112.5 $\mathrm{m}^{3} /$ detik dengan debit air maksimum yang tercatat yaitu $1080 \mathrm{~m}^{3} /$ detik (BPWC, 2011 dalam Oktaviani, 2015). Selain berfungsi sebagai sumber air PLTA Cirata, Waduk Cirata yang memiliki luas 6334 hektar tersebut sangat potensial untuk budidaya ikan dengan sistem keramba jaring apung (KJA), lalu lintas air, reservoir atau penyediaan air dan pengembangan pariwisata.

Usaha budidaya keramba jaring apung (KJA) merupakan mata pencaharian masyarakat sekitar waduk yang kehilangan pekerjaannya karena adanya relokasi akibat penenggelaman 32 desa dan 7 kecamatan dalam proses pembangunan Waduk Cirata. Pembudidayaan KJA meningkatkan perekonomian masyarakat sekitar dengan terbukanya lapangan pekerjaan dan peningkatan pendapatan masyarakat sekitar waduk. Pembudidayaan ikan tawar menggunakan sistem KJA dianggap sebagai usaha yang potensial, sehingga keberadaan KJA di Waduk Cirata mengalami peningkatan dari tahun ke tahun, hal ini ditandai dengan meningkatnya jumlah petak KJA di Waduk Cirata seperti disajikan pada Tabel1.

Meningkatnya aktivitas budidaya KJA dan aktivitas lainya di Waduk Cirata setiap tahun mengancam status keberlanjutan waduk dan budidaya KJA di waduk. Penurunan laju pertumbuhan ikan telah terjadi setelah terjadinya pencemaran, sedimentasi dan pertumbuhan tanaman eceng gondok.

Menurut Ummah (2015), aturan-aturan formal 
Tabel 1. Jumlah petani dan petak KJA tahun 2014 di Kab. Bandung Barat, Purwakarta dan Cianjur

\begin{tabular}{clrc}
\hline Zona & Kabupaten & Petani KJA & (Orang) \\
\hline 1 & Bandung Barat & 1.349 & $\begin{array}{c}\text { Petak KJA } \\
\text { (Unit) }\end{array}$ \\
2 & Purwakarta & 636 & 25.812 \\
3 & Cianjur & 1.496 & 11.775 \\
& Jumlah & 3.481 & 30.874 \\
& & & 68.461 \\
\hline
\end{tabular}

Sumber : Badan Pengelola Waduk Cirata (2015)

yang berlaku telah mengatur pengelolaan sumberdaya perikanan (KJA) yang mencakup tujuan ekonomi dan konservasi (perlindungan terhadap sumberdaya waduk), namun implementasi dari aturan tersebut belum berjalan. Oleh karena itu diperlukan kebijakan yang sesuai bagi pengelolaan Waduk Cirata terutama yang berkaitan dengan budidaya KJA yaitu kebijakan yang mampu menjembatani kepentingan beberapa pihak yang memanfaatkan Waduk Cirata terutama terkait status keberlanjutan waduk dan budidaya KJA.

\section{METODOLOGI}

Metode pengambilan data penelitian ini adalah purposive sampling. Menurut Sugiyono (2013) purposive sampling adalah teknik pengambilan sampel sumber data dengan pertimbangan tertentu. Pertimbangan tertentu ini, misalnya orang tersebut yang dianggap mengetahui tentang apa yang kita harapkan, atau mungkin dia sebagai penguasa sehingga akan memudahkan peneliti menjelajahi obyek atau situasi sosial yang diteliti. Responden yang dipilih sebanyak 44 responden, yang terdiri dari pembudidaya KJA, nelayan tangkap, anggota Masyarakat Peduli Cirata (MPC), Pokmaswas (kelompok masyarakat pengawas), Aspindac (asosiasi pedagang ikan danau Cirata), dan dinas perikanan.
Penelitian ini dilakukan di Waduk Cirata. Lokasi penelitian dipilih secara sengaja (purposive) dikarenakan karakteristik (pengeloaan mencakup tiga wilayah administratif) dalam pengelolaan sumberdaya di Waduk Cirata. Waduk Cirata merupakan salah satu waduk yang di dalamnya terdapat berbagai pihak yang memiliki kepentingan. Pengambilan data dilakukan pada bulan Maret - April 2016.

Jenis data yang digunakan dalam penelitian adalah data primer dan data sekunder. Penelitian ini bertujuan untuk menganalisis status keberlanjutan waduk dan perikanan di Waduk Cirata. Analisis status keberlanjutan waduk dilakukan dengan menganalisis tiga indikator keberlanjutan yaitu ekonomi, ekologi dan sosial.

Wawancara dan pengamatan lapangan dilakukan pada tiga zona wilayah Waduk Cirata yaitu zona I Kabupaten Cianjur, zona II Kabupaten Purwakarta dan zona III Kabupaten Bandung Barat. Definisi kriteria data dari atribut dilakukan melalui analisis data sebagai fakta data ekologi dalam atribut Rapfish.

\section{ANALISIS DAN ALTERNATIF SOLUSI PENANGANAN}

Berdasarkan kondisi lapangan, pada dimensi ekologi ditemukan 8 atribut yaitu: tingkat eksploitasi perikanan, frekuensi upwelling, pencemaran limbah KJA, pencemaran limbah 
Tabel 2. Realita data di lapangan dan nilai skor setiap atribut pada dimensi ekologi

\begin{tabular}{llccc}
\hline No & Atribut & Skor & Baik & Buruk \\
\hline 1 & Tingkat eksploitasi perairan waduk & 2,8 & 0 & 4 \\
2 & Frekuensi Upwelling & 0,8 & 3 & 0 \\
3 & Pencemaran limbah KJA & 0,3 & 3 & 0 \\
4 & Pencemaran limbah dari hulu & 0,7 & 3 & 0 \\
5 & Pencemaran limbah pertani an & 1,0 & 3 & 0 \\
6 & Pencemaran limbah domestik & 1,0 & 3 & 0 \\
7 & Tingkat sedimentasi & 0,4 & 2 & 0 \\
8 & Tingkat pertumbuhan eceng gondok & 0,1 & 3 & 0 \\
\hline
\end{tabular}

Sumber : Annisa, 2016

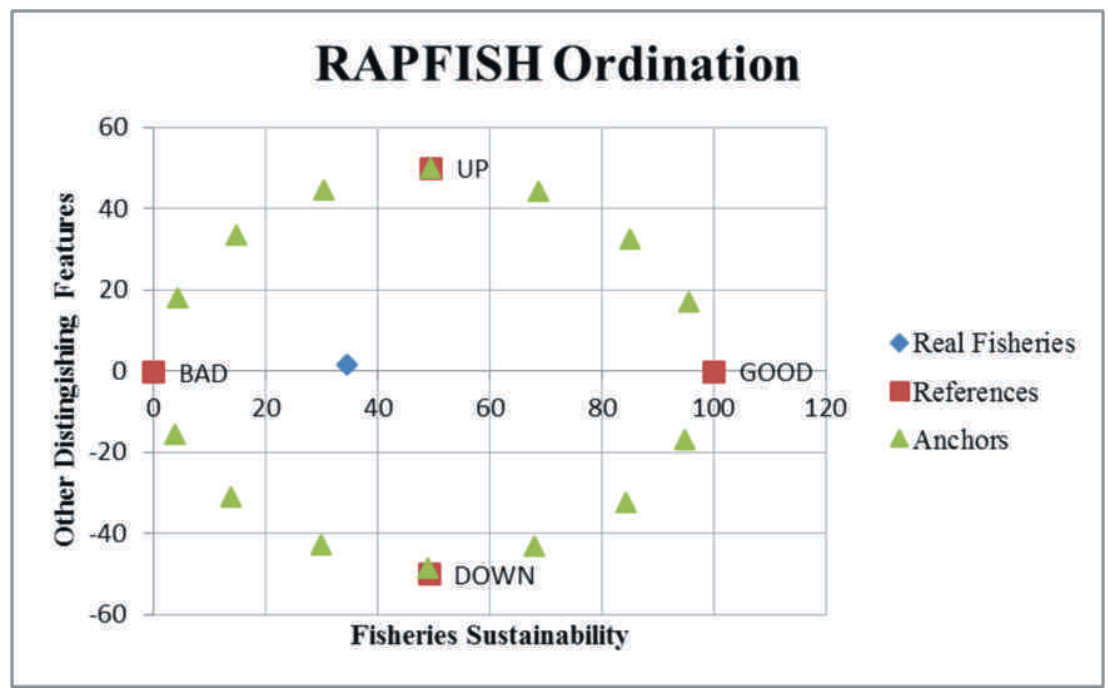

Gambar 1 Posisi status keberlanjutan Waduk Cirata pada dimensi ekologi

pertanian, pencemaran limbah dari hulu, pencemaran limbah domestik, tingkat sedimentasi, pertumbuhan enceng gondok. Berdasarkan rata-rata skor yang diperoleh dari wawancara stakeholder, petani KJA, nelayan tangkap maupun data sekunder yang diperoleh dari Badan Pengelola Waduk Cirata (BPWC) dan dinas terkait, skor untuk masing-masing atribut pada dimensi ekologi disajikan pada Tabel 2.

Tahapan dan analisis untuk menentukan status keberlanjutan ekologi Waduk Cirata telah dilakukan diantaranya: (1) penentuan skor dan indeks keberlanjutan, (2) penggambaran ordinasi rapfish pada dimensi ekologi, (3) uji kesalihan goodness of fit dengan prosedur multidemensional scaling (MDS), (4) penentuan nilai koefisien determinasi $\left(\mathrm{R}^{2}\right)$, (5) uji kestabilan ordinasi dengan teknik analisis Monte Carlo, (7) uji sensitivitas dengan metode analisis Leverage, (8) penentuan respons yang harus dilakukan terhadap atribut sensitif.

Hasil yang diperoleh dengan metode Rapfish tersebut menunjukkan nilai indeks keberlanjutan Waduk Cirata secara ekologi. Hasil analisis pada Tabel 2 disajikan pada Gambar 1, yang sekaligus menggambarkan ordinasi pada dimensi ekologi. Ordinasi Rapfish ini menggambarkan posisi keberlanjutan dimensi ekologi berdasarkan indeks keberlanjutan dimensi ekologi Waduk Cirata.

Berdasarkan Gambar 1 posisi status keberlanjutan waduk pada dimensi ekologi berada pada nilai indeks 34.70 atau dengan kata lain status 


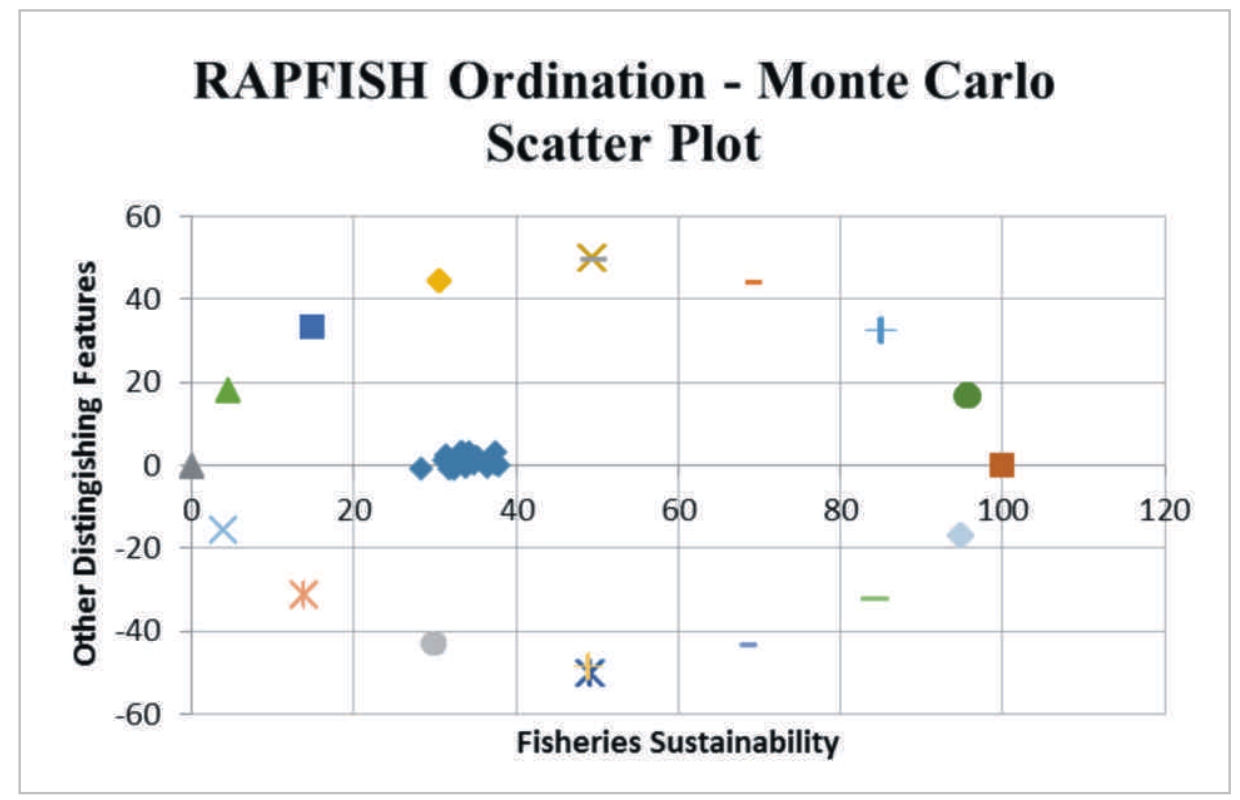

Gambar 2 Kestabilan nilai ordinasi hasil Rapfish dengan Monte Carlo pada dimensi ekologi

keberlanjuran Waduk Cirata pada status kurang berkelanjutan. Nilai stress yang diperoleh berdasarkan Gambar 1 posisi status keberlanjutan waduk pada dimensi ekonomi berada pada dimensi ekologi adalah $14.68 \%$.

Untuk mengetahui dampak kesalahan acak (random error) dilakukan metode simulasi Monte Carlo terhadap seluruh dimensi. Analisis ini untuk menunjukkan tingkat gangguan (perturbation) terhadap nilai ordinasi (Spence and Young dalam Hermawan, 2006). Hasil simulasi Monte Carlo untuk dimensi ekologi disajikan pada Gambar 2.

Atribut-atribut ekonomi yang digunakan perlu dianalisis menggunakan analisis laverage untuk mengetahui atribut mana yang sensitif mempengaruhi status keberlanjutan waduk. Perhitungan dilakukan dengan menggunakan metode stepwise yaitu dengan membuang setiap atribut secara berurutan satu persatu kemudian dihitung nilai error atau root meant square (RMS) tersebut dibandingkan dengan RMS yang dihasilkan pada saat seluruh atribut dimasukkan (Kavanagh dalam Hermawan, 2006). Nilai RMS dari dimensi ekologi pada analisis laverage dapat dilihat pada Gambar 3.

Kondisi sensitivitas yang demikian memperlihatkan bahwa perlu adanya respon atau kebijakan ekologi, khususnya pada permasalahan pencemaran air oleh limbah KJA. Pencemaran air yang terjadi di waduk Cirata merupakan salah satu indikasi akan terjadinya penurunan kualitas waduk baik sabagai fungsi utama maupun fungsinya sebagai perairan umum.

Penyusunan skor status keberlanjutan pada dimensi ekonomi waduk dilakukan berdasarkan kondisi lapangan daerah penelitian dan berdasarkan acuan kriteria yang telah dibuat. Untuk pendefinisian kriteria data dari atribut maka dilakukan analisis data sebagai fakta data ekonomi dalam atribut Rapfish. Berdasarkan kondisi lapangan dimensi ekonomi terdiri dari 7 atribut, yaitu: produktivitas perikanan KJA, keuntungan pemanfaatan pariwisata, keuntungan pemanfaatan perikanan tangkap, korosifitas instalasi PLTA, penyerapan tenaga kerja, potensi pengolahan pakan ikan alternatif dan hak kepemilikan usaha. 
Tabel 3 Nilai statistik yang diperoleh dari hasil analisis Rapfish pada dimensi ekologi

\begin{tabular}{llrr}
\hline No & Atribut statistik & Nilai statistik & Persentase \\
\hline 1 & Stress & 0,1468 & $14,68 \%$ \\
2 & $\mathrm{R}^{2}$ & 0,9475 & $94,75 \%$ \\
3 & Jumlah ilterasi & 2 & \\
\hline
\end{tabular}

Sumber: Skripsi, Zukruf A (2016)

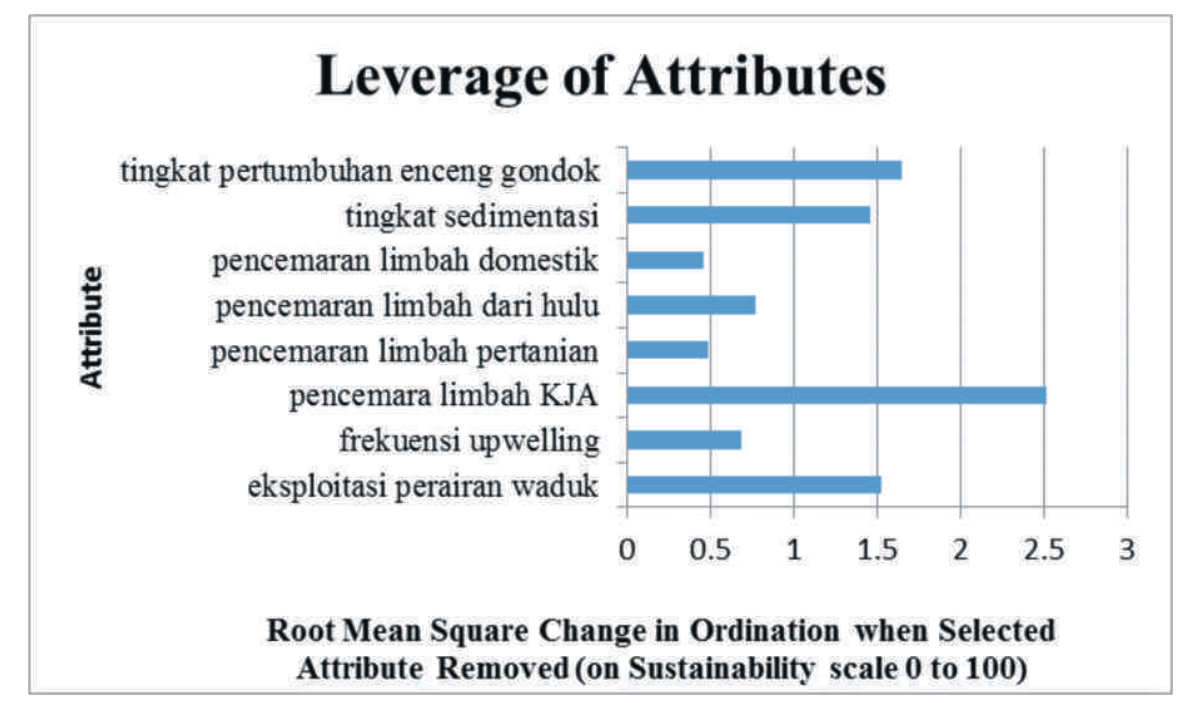

Gambar 3. Hasil analisis sensitivitas setiap atribut dimensi ekologi waduk

Berdasarkan rata-rata skor yang diperoleh dari wawancara stakeholder, petani KJA, nelayan tangkap maupun data sekunder yang diperoleh dari BPWC dan dinas terkait, skor untuk masingmasing atribut pada dimensi ekonomi disajikan pada Tabel 4.

Hasil analisis pada Tabel 4 dijelaskan pada Gambar 4, yang sekaligus menggambarkan ordinasi pada dimensi ekonomi. Ordinasi Rapfish ini menggambarkan posisi status keberlanjutan dimensi ekonomi berdasarkan indeks keberlanjutan dimensi ekonomi Waduk Cirata.

Pada Gambar 4 terlihat posisi status keberlanjutan waduk pada dimensi ekonomi berada pada nilai indeks 55.80 atau dengan kata lain status keberlanjutan waduk Cirata pada dimensi ekonomi berada pada status cukup berkelanjutan. Nilai statistik yang diperoleh dari MDS dalam Rapfish pada dimensi ekonomi disajikan pada Tabel 5. Hasil simulasi Monte Carlo untuk dimensi ekonomi disajikan pada Gambar 5.

Hasil analisis Monte Carlo dengan 25 kali pengulangan untuk dimensi ekonomi menunjukkan bahwa pengelolaan waduk Cirata telah mengalami gangguan (perturbation) yang ditunjukkan oleh plot yang menyebar. Nilai RMS dari dimensi ekonomi pada analisis leverage disajikan pada Gambar 6.

Analisis sensitivitas pada dimensi ekonomi dengan metode analisis Leverage pada Rapfish memperlihatkan bahwa atribut penyerapan tenaga kerja merupakan atribut pada dimensi ekonomi yang sangat berpengaruh terhadap status keberlanjutan waduk Cirata. Kebijakan untuk dapat menjaga status keberlanjutan waduk cirata dari dimensi ekonomi diarahkan pada pembatasan jumlah pembudidaya KJA yang disesuaikan dengan daya dukung waduk, mengutamakan penyerapan tenaga kerja lokal dan penciptaan lapangan kerja alternatif seperti usaha pengolahan 
Tabel 4. Realitas data di lapangan dan nilai skor setiap atribut pada dimensi ekonomi

\begin{tabular}{clrrr}
\hline No & \multicolumn{1}{c}{ Atribut } & Skor & Baik & Buruk \\
\hline 1 & Produktivitas perikanan KJA & 0,2 & 0 & 2 \\
2 & Keuntungan pemanfaatan pariwisata & 2,0 & 0 & 4 \\
3 & Keuntungan perikanan tangkap & 1,7 & 0 & 4 \\
4 & Tigkat korosifitas & 1,0 & 0 & 2 \\
5 & Penyerapan tenaga kerja & 1,9 & 2 & 0 \\
6 & Potensi pengelahan pakan ikan alternatif & 0,2 & 2 & 0 \\
7 & Kepemilikan usaha & 0,5 & 0 & 2 \\
\hline
\end{tabular}

Sumber : Annisa, 2016

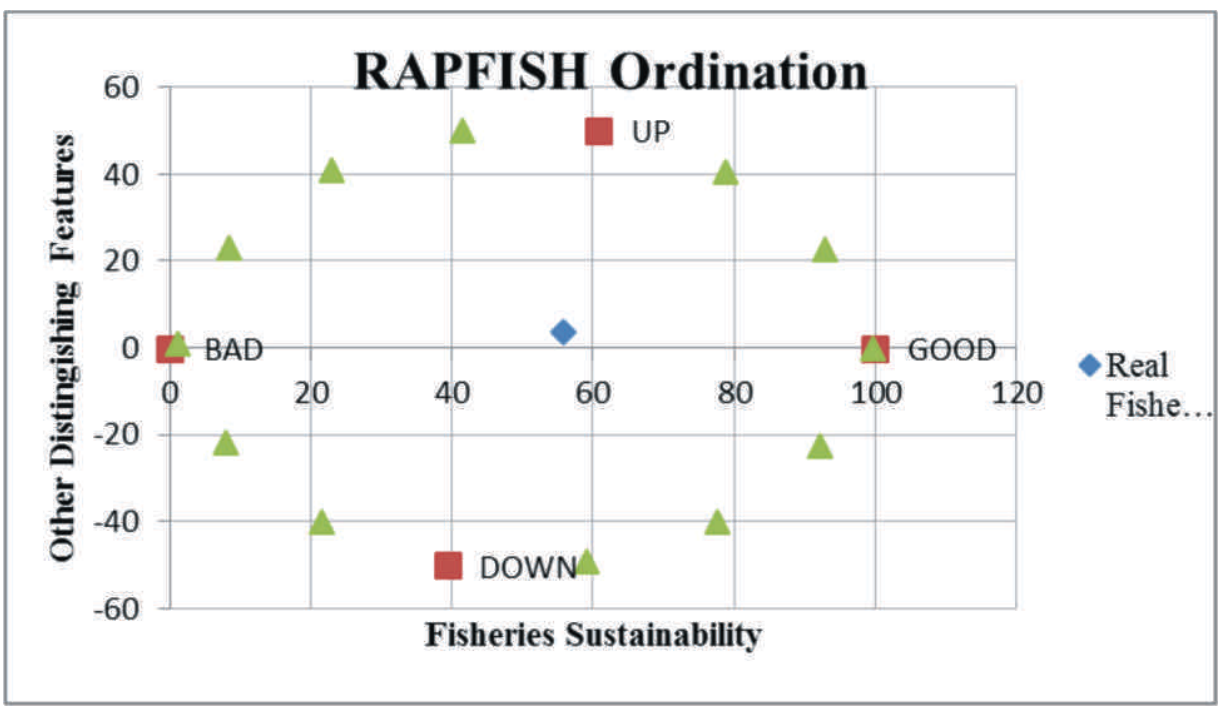

Gambar 4. Posisi status keberlanjutan Waduk Cirata pada dimensi ekonomi

pakan ikan, usaha pengolahan perikanan pasca panen sehingga tidak semua tenaga kerja bertumpu di sektor budidaya perairan waduk.

Penyusunan skor status keberlanjutan pada dimensi sosial waduk dilakukan berdasarkan kondisi lapangan daerah penelitian dan berdasarkan acuan kriteria yang telah dibuat. Untuk pendefinisian kriteria data dari atribut maka dilakukan analisis data sebagai fakta data sosial dalam atribut Rapfish. Berdasarkan kondisi lapangan, dimensi sosial terdiri dari 5 atribut, yaitu: eksistensi kelompok usaha perikanan, status konflik, keresahan yang dirasakan masyarakat, ancaman kehilangan pekerjaan, dan pengetahuan lingkungan hidup. Berdasarkan rata-rata skor yang diperoleh dari wawancara stakeholder, petani KJA, nelayan tangkap maupun data sekunder yang diperoleh dari BPWC dan dinas terkait, skor untuk masing-masing atribut pada dimensi sosial dapat dilihat pada Tabel 6.

Hasil pada Tabel 6 dijelaskan pada Gambar 7 yang juga menggambarkan ordinasi pada dimensi sosial waduk. Ordinasi ini menunjukkan posisi indeks keberlanjutan dimensi sosial waduk Cirata.

Pada Gambar 7 terlihat bahwa posisi status keberlanjutan waduk pada dimensi sosial berada pada nilai indeks 52.14 atau dengan kata lain status keberlanjutan waduk Cirata pada dimensi sosial berada pada ststus cukup berkelanjutan. Nilai statistik yang diperoleh dari MDS dalam rapfish pada dimensi sosial disajikan pada Tabel 7.

Tabel 7 menunjukkan nilai koefisien determinasi atau selang kepercayaan $\left(\mathrm{R}^{2}\right)$ sebesar 93.69\% yang artinya model dengan menggunakan 
Tabel 5. Nilai statistik yang diperoleh dari hasil analisis Rapfish pada dimensi ekonomi

\begin{tabular}{llrr}
\hline No & Atribut statistik & Nilai statistik & Presentase \\
\hline 1 & Stress & 0,1447 & $14,47 \%$ \\
2 & $\mathrm{R}^{2}$ & 0,9474 & $94,74 \%$ \\
3 & Jumlah ilterasi & 2 & \\
\hline
\end{tabular}

Sumber : Annisa, 2016

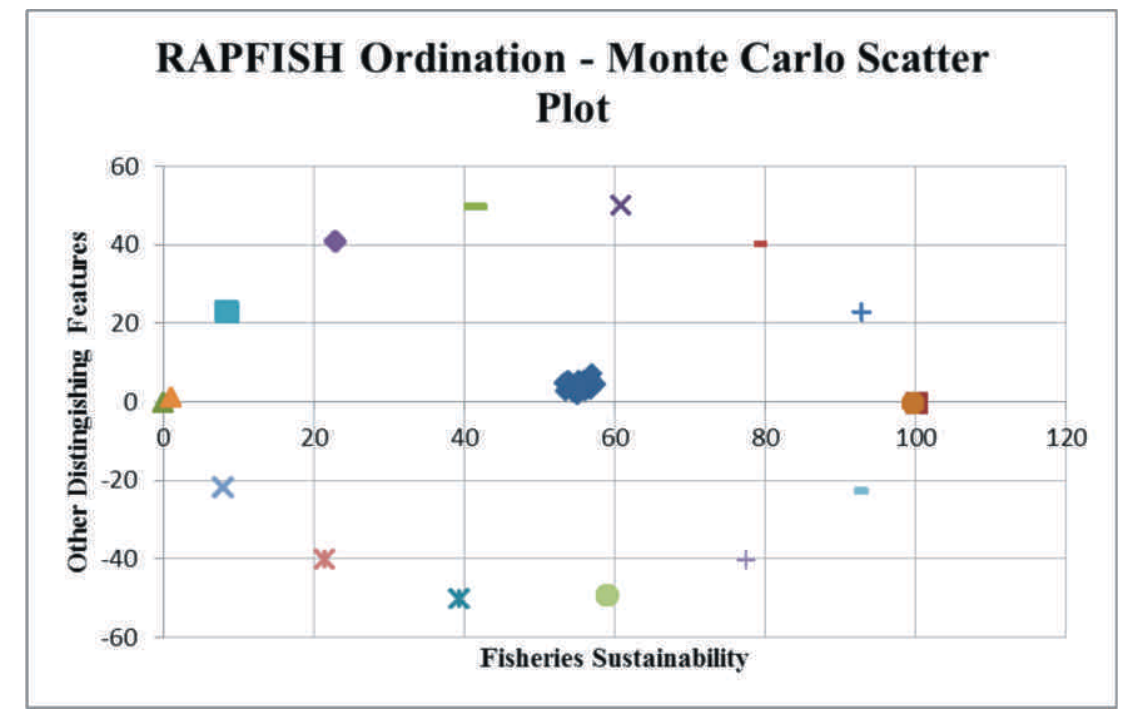

Gambar 5. Kestabilan nilai ordinasi hasil Rapfish dengan Monte Carlo pada dimensi ekonomi

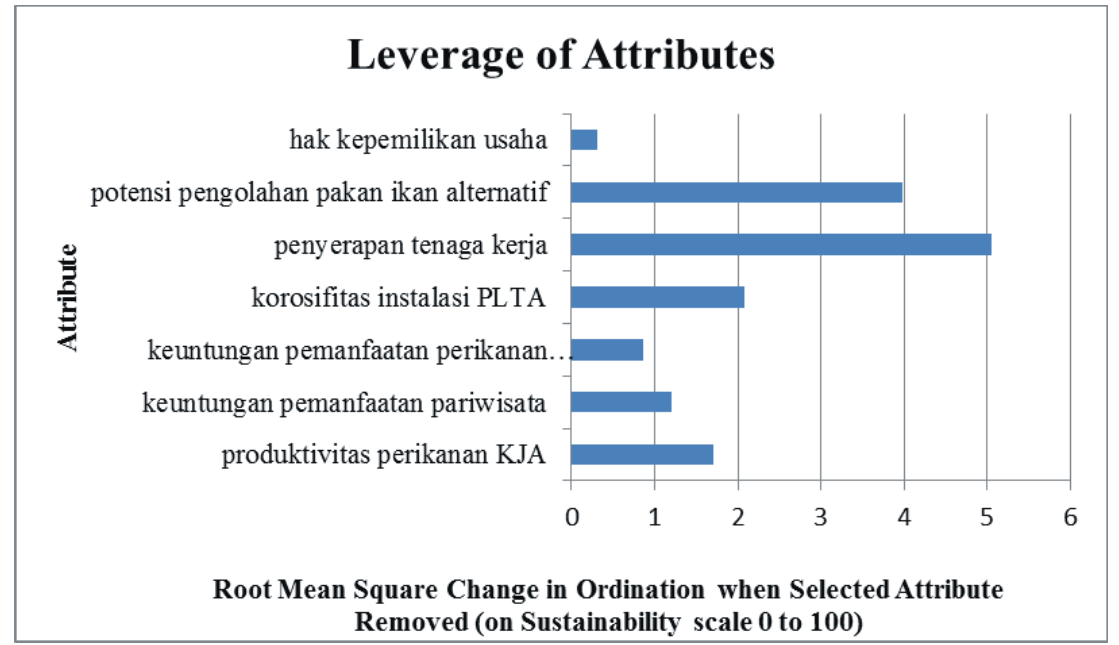

Gambar 6. Hasil analisis sensitivitas setiap atribut ekonomi waduk

peubah-peubah saat ini sudah menjelaskan 93.69\% dari model yang ada. Analisis ini untuk menunjukkan tingkat gangguan (perturbation) terhadap nilai ordinasi (Spence and Young dalam Hermawan, 2006). Hasil simulasi Monte Carlo untuk dimensi sosial disajikan pada Gambar 8.
Hasil analisis Monte Carlo dengan 25 kali pengulangan untuk dimensi sosial menunjukkan bahwa pengelolaan waduk Cirata telah mengalami gangguan (perturbation) yang ditunjukkan oleh plot yang menyebar. Nilai RMS dari dimensi sosial pada analisis laverage disajikan pada Gambar 9. 
Tabel 6. Realitas data di lapang dan nilai skor setiap atribut pada dimensi sosial

\begin{tabular}{llrrr}
\hline No & Atribut & Skor & Baik & Buruk \\
\hline 1 & Eksistensi kelompok usaha perikanan & 1,0 & 2 & 0 \\
2 & Status konflik & 0,3 & 0 & 2 \\
3 & Keresahan yang dirasakan masyarakat & 1,6 & 0 & 2 \\
4 & Ancaman kehilangan pekerjaan & 0,6 & 0 & 2 \\
5 & Pengetahuan terhadap lingkungan hidup & 1,2 & 2 & 0 \\
\hline
\end{tabular}

Sumber : Annisa, 2016

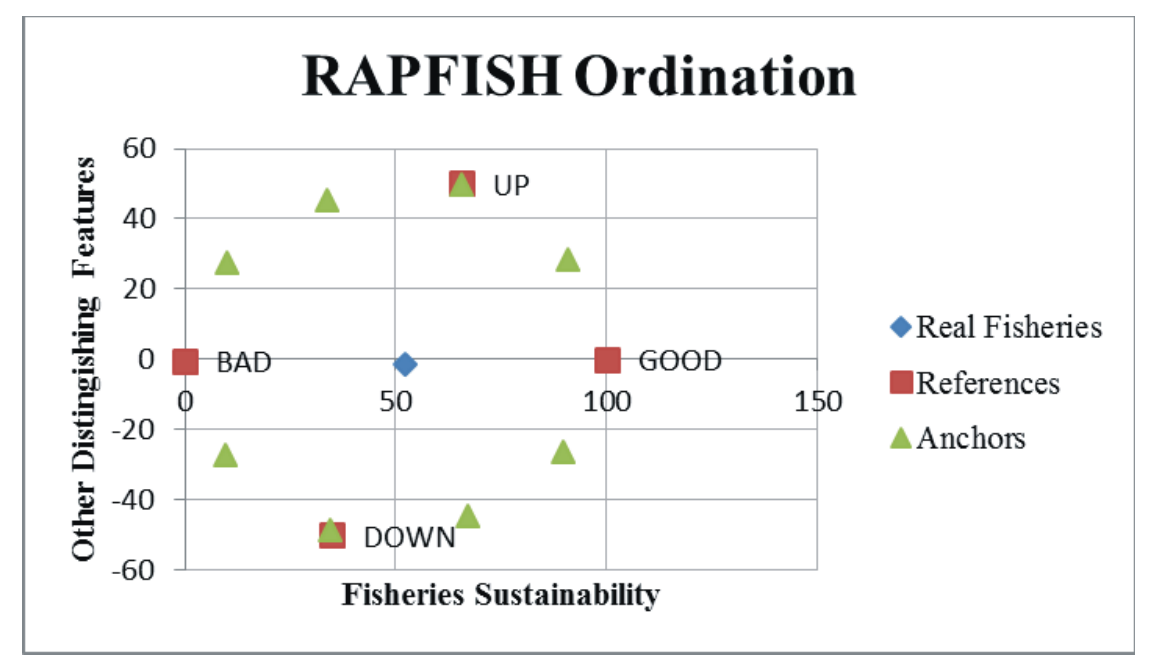

Gambar 7. Posisi status keberlanjutan Waduk Cirata pada dimensi sosial

Tabel 7 Nilai statistik yang diperoleh dari hasil analisis Rapfish pada dimensi sosial

\begin{tabular}{|c|c|c|c|}
\hline No & Atribut statistik & Nilai statistik & Persentase \\
\hline 1 & Stress & 0,1649 & $16,49 \%$ \\
\hline 2 & $\mathrm{R}^{2}$ & 0,9369 & $93,69 \%$ \\
\hline 3 & Jumlah ilterasi & 3 & \\
\hline
\end{tabular}

Sumber : Annisaa, 2016

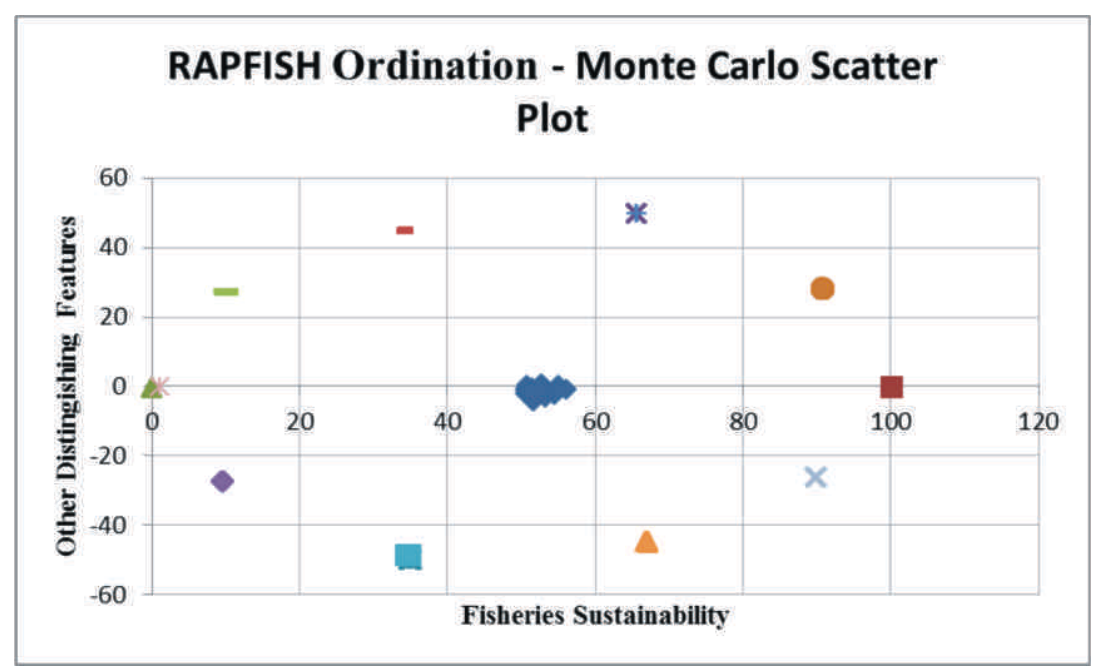

Gambar 8. Kestabilan nilai ordinasi hasil Rapfish dengan Monte Carlo pada dimensi sosial 
Analisis sensitivitas pada dimensi sosial dengan metode analisis leverage pada rapfish memperlihatkan bahwa atribut keresahan yang dirasakan masyarakat sekitar waduk merupakan atribut pada dimensi sosial yang sangat berpengaruh terhadap status keberlanjutan waduk Cirata. Menurut Fauzi (2004) nilai perbedaan $<5$ menunjukkan bahwa: (1) kesalahan dalam pembuatan skor setiap atribut relatif kecil, (2) ragam pemberian skor akibat perbedaan pendapat atau penilaian yang relatif kecil, (3) proses analisis yang dilakukan berulang relatif stabil, (4) kesalahan data dan data yang hilang dapat dihindari. Perbedaan indeks setiap dimensi disajikan pada Tabel 8 dan Tabel 9.
Pada Tabel 8 dan Tabel 9 terlihat bahwa selisih setiap dimensi $<5$, maka dapat disimpulkan bahwa hasil analisis keberlanjutan pada setiap dimensi waduk dan KJA memiliki tingkat kesalahan skoring yang relatif kecil, ragam pemberian skor relatif kecil, proses analisis yang stabil dan telah dihindari kesalahan data atau data yang hilang.

Produksi budidaya perikanan dipengaruhi oleh tiga faktor, yaitu: kondisi media (air), kualitas benih dan kualitas pakan. Pakan yang merupakan komponen tertinggi dalam struktur biaya operasi budidaya ikan mencapai $40-70 \%$ dari biaya operasi. Harga pakan sangat berperan dalam menentukan tinggi atau rendahnya biaya produksi ikan. Selanjutnya, biaya produksi ikan akan menentukan

Tabel 8 Perbedaan indeks setiap dimensi keberlanjutan waduk

\begin{tabular}{clrrr}
\hline No & \multicolumn{1}{c}{ Dimensi } & Indeks MDS & Indeks Monte Carlo & Perbedaan \\
\hline 1 & Ekologi & 34,70 & 33,72 & 0,98 \\
2 & Ekonomi & 55,80 & 55,30 & 0,50 \\
3 & Sosial & 52,14 & 52,00 & 0,14 \\
\hline
\end{tabular}

Sumber : Annisa, 2016

Tabel 9 Perbedaan indeks setiap dimensi keberlanjutan budidaya KJA

\begin{tabular}{clrrr}
\hline No & \multicolumn{1}{c}{ Dimensi } & Indeks MDS & Indeks Monte Carlo & Perbedaan \\
\hline 1 & Ekologi & 29,07 & 28,98 & 0,09 \\
2 & Ekonomi & 54,28 & 54,84 & 0,56 \\
3 & Sosial & 49,52 & 49,43 & 0,09 \\
\hline
\end{tabular}

Sumber : Annisa, 2016

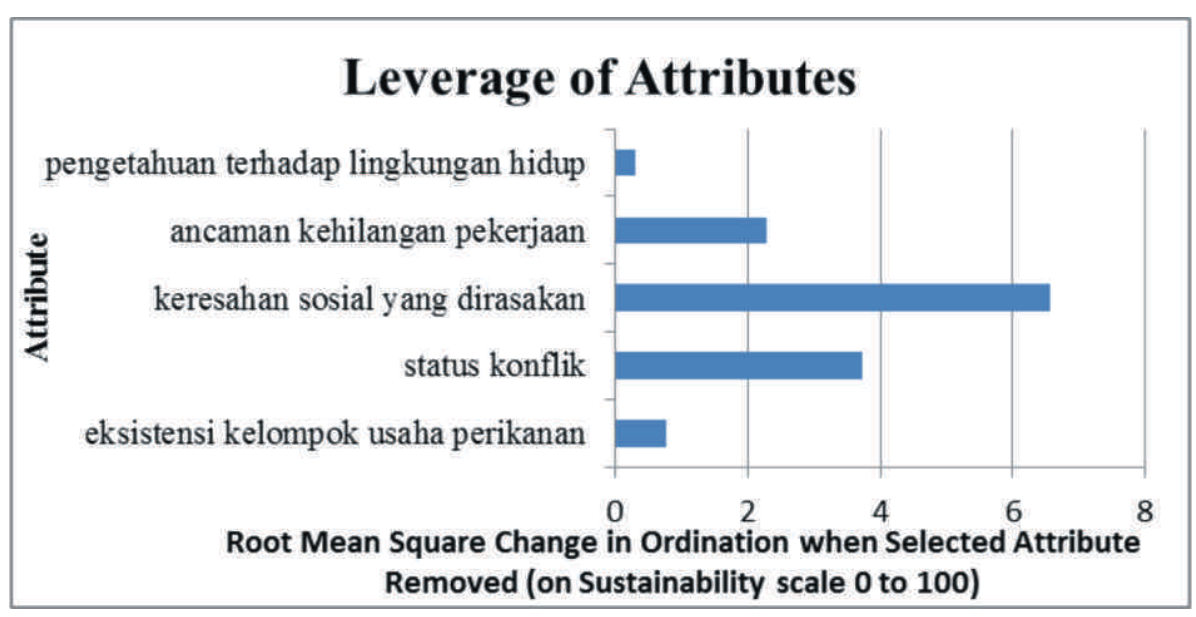

Gambar 9. Hasil analisis sensitivitas setiap atribut dimensi sosial waduk 
daya saing ikan di pasar domestik. Disisi lain bahan baku pakan ikan sebagian besar diimpor, produk dalam negeri biasanya kualitasnya lebih rendah dan harganya relatif lebih mahal. Hal ini tentu akan menjadi penghambat keberlanjutan perikanan budidaya secara ekonomi.

Permasalahan penurunan kualitas lingkungan perairan dilihat dari sisi penggunaan pakan dalam perikanan budidaya selalu mengalami inefisiensi. Budidaya perairan akan menghasilkan sisa pakan ikan budidaya. Sampai batas tertentu buangan pakan tersebut bermanfaat karena meningkatkan produksi ikan, tetapi apabila melebihi batas tertentu zat tersebut akan menjadi pencemar. Zat hara utama yang mencemari lingkungan air tawar adalah fosfor. Akibatnya, bila hal ini tidak diperhitungkan dengan sistem rantai makanan dan daya dukung lingkungan tentu akan menyebabkan pencemaran dan aktivitas perikanan budidaya pada akhirnya menjadi tidak berkelanjutan.

Jaminan keberadaan lokasi perikanan budidaya didalam Tata Ruang juga menjadi suatu permasalahan yang sangat urgent. Kepastian hukum dalam arti fisik sangat diperlukan agar terjaminnya lokasi budidaya yang tidak bisa diganggu gugat atau diusir oleh peruntukan lain selain dari perikanan budidaya. Kepastian hukum dalam arti fungsional bermakna terlaksananya fungsi perikanan budidaya dengan baik, sehingga terdapat jaminan bahwa perairan yang ada tidak akan tercemari baik oleh limbah industri, pertanian ataupun rumah tangga yang berada dibagian hulu DAS (Daerah Aliran Sungai) yang mengalir di kawasan tersebut. Namun faktanya tidak sedikit masalah yang timbul akibat adanya konflik kepentingan penggunaan ruang antara perikanan budidaya dengan kegiatan sektor lain. Hal ini tentu juga akan menjadi penghambat dalam mewujudkan perikanan budidaya yang berkelanjutan.

Keberlanjutan Waduk Cirata secara keseluruhan sangat dipengaruhi oleh pemanfaatan waduk sebagai PLTA maupun sebagai perairan umum terutama pemanfaatan waduk sebagai budidaya keramba jaring apung, karena kegiatan

Tabel 10. Indeks keberlanjutan menggunakan analisis Rapfish Waduk dan KJA di Waduk Cirata

\begin{tabular}{clrrrc}
\hline No & & Keberlanjutan & Ekologi & Ekonomi & Sosial \\
\hline 1 & Waduk & 34,70 & 55,80 & 52,14 \\
2 & KJA & 29,07 & 54,28 & 49,52 \\
\hline
\end{tabular}

Sumber : Annisa, 2016

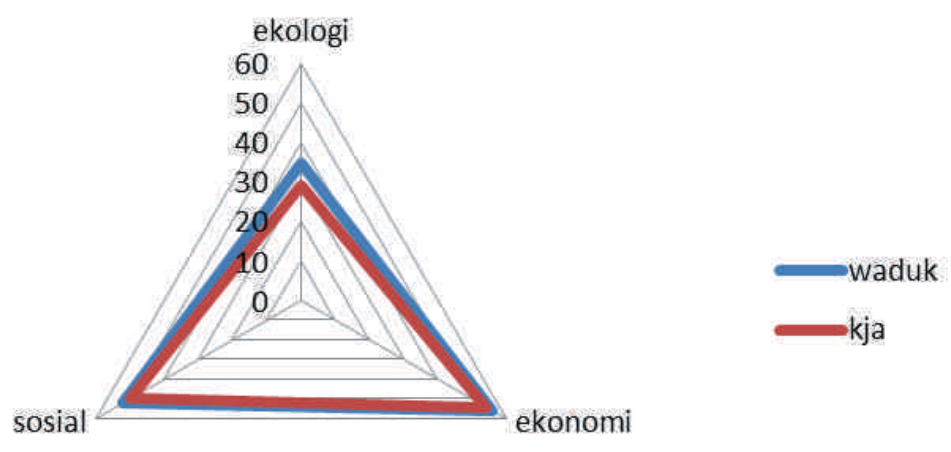

Gambar 10. Diagram radar keberlanjutan terhadap dimensi ekologi, ekonomi dan sosial waduk dan KJA di Waduk Cirata 
tersebut akan menimbulkan eksternalitas positif dan negatif yang mempengaruhi kualitas perairan, disisi lain penurunan kualitas perairan ini menjadi penghambat dalam usaha budidaya KJA yang berkelanjutan.

Keberlanjutan waduk maupun keberlanjutan budidaya KJA satu sama lain sangat mempengaruhi, pengelolaan yang berkelanjutan pada waduk akan mempengaruhi keberlanjutan budidaya KJA. Pengelolaan yang berkelanjutan pada budidaya KJA akan mendukung keberlanjutan Waduk Cirata secara keseluruhan, sebaliknya buruknya pengelolaan waduk atau budidaya KJA akan menjadi penghambat bagi terwujudnya pengelolaan yang berkelanjutan. Hasil analisis indeks keberlanjutan waduk dan budidaya KJA disajikan pada Tabel 10, selain itu perbandingan keberlanjutan waduk dan budidaya KJA disajikan pada Gambar 10.

\section{REFERENSI}

Annisaa, Z. 2016. Analisis Keberlanjutan Ekologi, Ekonomi, Sosial Waduk dan Budidaya Keramba Jaring Apung di Waduk Cirata [Skripsi]. Bogor (ID): Institut Pertanian Bogor.

Bukit, N.T., Yusuf, I.A. 2002. Beban Pencemaran Limbah Industri dan Status
Hermawan, M. 2006. Keberlanjutan Perikanan Tangkap Skala Kecil (Kasus Perikanan Pantai Di Serang Dan Tegal). [Tesis]. Bogor (ID) : Institut Pertanian Bogor.

Linsley, K.R., Franzini, B.J. 1989. Teknik Sumberdaya Air. Jakarta (ID): Erlangga.

Oktaviani, D.A. 2015. Status Keberlanjutan Pengelolaan Waduk Cirata Provinsi Jawa Barat. [Skripsi]. Bogor (ID) : Institut Pertanian Bogor.

Surat Keputusan Gubernur Jawa Barat Nomor 41/2002 tentang. Pengembangan dan Pemanfaatan Lahan Pertanian dan Kawasan Waduk.

Sugiyono. 2013. Metode Penelitian Kuantitatif, Kualitatif dan R\&D. Bandung (ID) : CV Alfabeta.

Ummah, N.W. 2015. Analisis Kelembagaan Dalam Pengelolaan Keramba Jaring Apung (KJA) Waduk Cirata. Bogor (ID) : Institut Pertanian Bogor.

Widiyati, A. 2011. Rancang Bangun Model Pengelolaan Waduk Berkelanjutan Berbasis Perikanan Budidaya Karamba Jaring Apung (Kasus Waduk Cirata Jawa Barat). Bogor (ID) : Institut Pertanian Bogor.

Zukruf, A. 2106. Analisis Kenerlanjutan Ekologi, Ekonomi, Sosial Waduk dan Budidaya Keramba Jaring Apung di Waduk Cirata. Bogor (ID) : Institut Pertanian Bogor. 